ORIGINAL

\title{
Prevalence of stereotypies in thoroughbred race horses at Club Hípico Concepción, Chile
}

\section{Prevalencia de estereotipias en caballos fina sangre de carrera del Club Hípico Concepción, Chile}

\author{
Lisandro Muñoz $A,{ }^{1 *}$ M.Sc, Felipe Ainardi $C,{ }^{1} M V$, Christian Rehhof $V^{1}{ }^{1}$ MV, \\ Jaime Cruces $L,{ }^{1} M V$, Reinaldo Ortiz $R,{ }^{1} M V$, Mario Briones $L,{ }^{2} M . S c$.
}

\begin{abstract}
Universidad de Concepción, Facultad de Ciencias Veterinarias. ${ }^{1}$ Departamento de Ciencias Clínicas, ²Departamento de Ciencias Pecuarias, Victoria 495. Concepción, Chile. *Correspondencia: lismunoz@ udec.cl
\end{abstract}

Received: September 2013; Accepted: February 2014.

\begin{abstract}
Objective. To determine the prevalence of classic stereotypies in Thoroughbred racehorses at the Club Hípico Concepción ( $\mathrm{CHC}$ ) in Chile and its association with sex and age. Materials and methods. The entire population of resident horses at the $\mathrm{CHC}$ was studied $(n=341)$. Each horse trainer $(n=23)$ was asked for the name, sex and age of the horses under his/her supervision. After that, all the animals were continuously observed inside their stalls for 8 hours by only one person, to record the absence or presence of classic stereotypies (cribbing, weaving, stall-walking). To analyze the data, the animals were divided by sex into 3 groups: stallions, geldings and mares. According to age, they were divided into 2 groups: < 5 years old and 5 years old or more. Descriptive statistics were used and association was tested using the chi square test using $\mathrm{p} \leq 0.05$. Results. $13.2 \%$ of all $\mathrm{CHC}^{\prime} \mathrm{s}$ horses displayed stereotypies: cribbing $(4.99 \%)$, weaving $(2.93 \%)$ and stall-walking $(5.28 \%)$. No association was found between the presence of stereotypies and sex or age. Conclusions. Thoroughbred race horses at the $\mathrm{CHC}$ showed a high prevalence of classic stereotypies, especially stall-walking.
\end{abstract}

Key words: Cribbing, equine, stall-walking, stereotyped behavior, weaving (Source: MeSH).

\section{RESUMEN}

Objetivo. Determinar la prevalencia de estereotipias clásicas en caballos fina sangre de carrera (FSC) del Club Hípico Concepción (CHC), Chile y su asociación con el sexo y la edad. Materiales y métodos. Se estudió la totalidad de los caballos FSC $(n=341)$ residentes en el CHC. A cada entrenador $(n=23)$, se le consultó nombre, sexo y edad de los caballos a su cargo. Luego, con la finalidad de detectar la presencia o ausencia de estereotipias clásicas (aerofagia, balanceo y caminar en pesebrera), durante 8 horas una sola persona observó directamente los caballos mientras se encontraban en sus pesebreras. Los caballos se dividieron por sexo en 3 grupos: machos enteros, machos castrados y hembras. De acuerdo con la edad se dividieron en 2 grupos: $<5$ años y 5 años o más. Los resultados en la parte descriptiva se entregan como porcentajes simples y para el análisis estadístico de las variables sexo y edad, se utilizó la prueba de $X^{2}$, con un nivel de significancia de $p<0.05$. Resultados. El $13.2 \%$ de los caballos de $\mathrm{CHC}$ presentaron estereotipias: aerofagia $(4.99 \%)$, balanceo $(2.93 \%)$ y caminar en 
pesebrera $(5.28 \%)$. No se encontró asociación entre la presencia de estereotipias y las variables sexo y edad. Conclusiones. Los caballos FSC del CHC presentan una alta prevalencia de estereotipias clásicas, principalmente caminar en pesebrera.

Palabras clave: Aerofagia, balanceo estereotipado, caminar en pesebrera, comportamiento estereotipado, equino (Fuente: MeSH).

\section{INTRODUCTION}

In the wild, horses live in groups of 3-10 individuals, providing them with security and allowing them to have intense social interaction. They can also walk up to 65 to $80 \mathrm{~km}$ (1) and spend about $80 \%$ of the day feeding (2). For this reason, captivity and handling associated with domestication have compromised their nutritional, social, sexual and kinetic behavior, which in some horses has stimulated the development of abnormal behaviors and stereotypies. Stereotypies are defined as repetitive behavior that is relatively unchanged and has no apparent function (1). Therefore, the presence of a stereotypy is indicative of a welfare problem (2). In horses, the most common stereotypies (also called classic stereotypies) are cribbing, weaving and stall-walking. In some countries, these stereotypies must be declared at auctions, and in general, tend to decrease the price of horses (1). Worldwide, several studies have been performed to determine the frequency and risk factors associated with these stereotypies (3-20). However, within the risk factors, sex and age have shown very contradictory results $(1,3,9-13,16,19-23)$. However, none of the studies' results were based on information obtained from direct observation of an entire determined population, but from direct observation of a sample of a population $(13,16,20)$ or on information provided by the owners through personal interviews or surveys conducted at a distance by telephone, mail or email $(3-12,14,15,17-19)$.

The aim of this study was to determine, by direct observation, the prevalence of classic stereotypies in all Thoroughbred racehorses (FSC) at the Concepción Equestrian Club (Chile) and their association with gender and age.

\section{MATERIALS AND METHODS}

Study site and geo-climate. Concepción Equestrian Club (CHC), Biobío Region, Chile (36047'32"S; 73005'44"W). Warm temperate climate with dry summers, high humidity and less than $50 \mathrm{~m}$ above sea level (24).

Animals studied. All Thoroughbred horses residing at the $\mathrm{CHC}$ were studied $(n=341)$, with

\section{INTRODUCCIÓN}

En vida silvestre, los equinos viven en grupos de 3 a 10 individuos, lo que les brinda seguridad y les permite desplegar una intensa interacción social, además, pueden caminar hasta 65 a 80 km (1) y ocupar cerca del $80 \%$ del día alimentándose (2). Razón por la cual, el cautiverio y los manejos asociados a la domesticación, han comprometido su comportamiento alimenticio, social, sexual y cinético, lo que en algunos equinos ha estimulado el desarrollo de comportamientos anormales y dentro de éstos de estereotipias. Las estereotipias son definidas como un comportamiento repetitivo, relativamente invariable y sin una función aparente (1). Por lo que, la presencia de una estereotipia es indicativa de un problema de bienestar (2). En equinos, las estereotipias más comunes (también llamadas clásicas) son aerofagia, balanceo y caminar en pesebrera. Estas estereotipias en algunos países deben ser obligatoriamente declaradas en los remates y en general, tienden a disminuir el precio de los equinos (1). En el mundo, se han realizado varios estudios tendientes a establecer la frecuencia y factores de riesgo asociados a estas estereotipias (3-20). Sin embargo, dentro de los factores de riesgo, el sexo y la edad han mostrado resultados muy contradictorios $(1,3,9-$ $13,16,19-23)$. No obstante, en ninguno de los estudios realizados los resultados se basaron en información obtenida por observación directa del total de una población determinada, sino que en observación directa de una muestra de una población $(13,16,20)$, o bien en información entregada por los propietarios a través de entrevistas personales o encuestas realizadas a distancia por teléfono, correo o correo electrónico (3-12,14,15,17-19).

El objetivo del presente estudio fue determinar por observación directa la prevalencia de estereotipias clásicas en la totalidad de los caballos fina sangre de carrera (FSC) residentes del Club Hípico Concepción (Chile) y su asociación con el sexo y la edad.

\section{MATERIALES Y MÉTODOS}

Sitio del estudio y geoclima. Club Hípico Concepción ( $\mathrm{CHC})$, Región del Biobío, Chile 
an age range of 2-13 years. All were enclosed for more than 22 hours a day in individual stalls with shavings, without any physical contact with other horses, without access to paddocks or pastures, and kept on a diet of grain, hay and water ad libitum. All horses had a similar training program that consisted of one or more of the following activities performed 1 or 2 times a day: walking (20-30 minutes), galloping riderless in a round pen (20 minutes) and galloping with a rider at different intensities (5-10 minutes). Horses that were competing the following day would not receive exercise.

Recording Stereotypies. Each trainer $(n=23)$, was asked the name, sex and age of the horses in their care. Then, based on an ethogram (Table 1) and with the purpose of identifying and detecting the presence or absence of classic stereotypies (or cribbing, weaving and stallwalking), a continuous recording system (25) was used. The study was conducted between January $3^{\text {rd }}$ and February $25^{\text {th }}, 2008$. Each day, and per block (where there are several individual stalls whose doors open onto a hallway or common area) for 8 hours divided into two direct, continuous observation periods ( $8: 00$ to 13:00 hours and $14: 00$ to $17: 00$ hours), one person directly observed all horses while they were in their stalls. The horses were divided by sex into 3 groups: stallions $(n=50)$, geldings $(n=173)$ and mares $(n=118)$. They were also divided into 2 groups according to age: $<5$ years $(n=213)$ and 5 years or more $(n=128)$.

Table 1. Ethogram of observed stereotypies.

\begin{tabular}{ll}
\hline Stereotypy & Description \\
\hline Cribbing & $\begin{array}{l}\text { The horse, with or without supporting the } \\
\text { upper incisors on any solid material, tenses } \\
\text { the neck muscles, forcing the entry of air into } \\
\text { the cranial portion of the esophagus, making } \\
\text { a characteristic noise. }\end{array}$ \\
Weaving & $\begin{array}{l}\text { The horse moves its head from side to side, } \\
\text { alternately putting its weight on the forelimbs. }\end{array}$ \\
Stall-walking & $\begin{array}{l}\text { The horse walks, trots, or canters around the } \\
\text { interior perimeter of the stall. }\end{array}$
\end{tabular}

Descriptions adapted by Tadich et al (20) and McDonnell (2).

Analysis of results. The results in the description are presented as percentages. For statistical analysis of the sex and age variables, the $X^{2}$ test was used, and alternatively Fisher's exact test was used when a result was $<5$. Both tests had a significance level of $p \leq 0.05$.

\section{RESULTS}

Forty-five (13.2\%) of the horses at $\mathrm{CHC}$ had stereotypies: 17 (4.99\%) cribbing, 10 (2.93\%)
(36047'32"S; 73005'44"O). Clima templado cálido con verano seco, gran humedad atmosférica y a menos de $50 \mathrm{~m}$ sobre el nivel del mar (24).

Animales del estudio. Se estudió la totalidad de los caballos FSC $(n=341)$ residentes en el $\mathrm{CHC}$, con un rango de edad de 2 a 13 años. Todos estabulados por más de 22 horas diarias, en pesebreras individuales, con cama de viruta, sin contacto físico con otros caballos, sin acceso a corrales ni a pastoreo, mantenidos con una alimentación basada en avena en grano, heno de alfalfa y agua ad libitum. Todos los caballos tenían un programa de entrenamiento similar que consistía en una o más de las siguientes actividades realizadas 1 ó 2 veces al día: paseo de tiro al paso (20 a $30 \mathrm{~min}$ ), galope sin jinete en picadero circular ( $20 \mathrm{~min})$ y galope con jinete a diferentes intensidades (5 a $10 \mathrm{~min}$ ). Los caballos que competían al día siguiente no realizaban ejercicio.

Registro de estereotipias. A cada entrenador $(n=23)$, se le consultó nombre, sexo y edad de los caballos a su cargo. Luego, basado en un etograma (Tabla 1) y con la finalidad de identificar y detectar la presencia o ausencia de estereotipias clásicas (aerofagia, balanceo y caminar en pesebrera), se utilizó un sistema de registro continuo (25). El estudio se realizó entre el 3 de enero y el 25 de febrero del año 2008. En un día por cuadra (lugar en donde hay varias pesebreras individuales cuyas puertas dan hacia un pasillo o área común), durante 8 horas divididas en 2 períodos de observación directa y continua (8:00-13:00 horas y 14:00-17:00 horas), una sola persona observó directamente todos los caballos mientras se encontraban en sus pesebreras. Los caballos se dividieron por sexo en 3 grupos: machos enteros $(n=50)$, machos castrados $(n=173)$ y hembras $(n=118)$. De acuerdo con la edad, se dividieron en 2 grupos: $<5$ años $(n=213)$ y 5 años o más $(n=128)$.

Análisis de resultados. Los resultados en la parte descriptiva se presentan como porcentajes simples. Para el análisis estadístico de las variables sexo y edad, se utilizó la prueba de $X^{2}$ y alternativamente la prueba exacta de Fisher cuando un resultado era $<5$. Ambas pruebas con un nivel de significancia de $p<0.05$.

\section{RESULTADOS}

Cuarenta y cinco (13.2\%) de los caballos del CHC presentaron estereotipias: $17(4.99 \%)$ aerofagia, $10(2.93 \%)$ balanceo y $18(5.28 \%)$ caminar en pesebrera. En la tabla 2 se muestra la prevalencia de estereotipias clásicas en caballos FSC del CHC de acuerdo con el sexo. 
weaving and $18(5.28 \%)$ stall-walking. Table 2 shows the prevalence of classic stereotypies in Thoroughbred horses at $\mathrm{CHC}$ according to sex.

Table 2. Prevalence of classic stereotypies in Thoroughbred racehorses at the Club Hípico Concepción, according to sex $(n=341)$.

\begin{tabular}{lccc}
\hline & \multicolumn{3}{c}{ Sex } \\
\cline { 2 - 4 } Stereotypy & $\begin{array}{c}\text { Stallions } \\
(\mathbf{n = 5 0 )}\end{array}$ & $\begin{array}{c}\text { Geldings } \\
(\mathbf{n = 1 7 3 )}\end{array}$ & $\begin{array}{c}\text { Mares } \\
(\mathbf{n = 1 1 8})\end{array}$ \\
\hline Cribbing \% & 4 & 4.04 & 6.77 \\
Weaving \% & 4 & 3.46 & 1.69 \\
Stall-walking \% & 8 & 2.31 & 8.47 \\
Total & 16 & 9.81 & 16.93 \\
\hline
\end{tabular}

No association was found between the presence of individual and total classic stereotypies in connection to the sex variable ( $p>0.05)$.

Table 3 shows the prevalence of classic stereotypies in Thoroughbred horses at $\mathrm{CHC}$ according to age.

Table 3. Prevalence of classic stereotypies in Thoroughbred racehorses at the Club Hípico Concepción, according to age. $(\mathrm{N}=341)$.

\begin{tabular}{lcc}
\hline & \multicolumn{2}{c}{ Age } \\
\cline { 2 - 3 } Stereotypy & $\begin{array}{c}\text { < } \mathbf{5} \text { years } \\
(\mathbf{n = 2 1 3 )}\end{array}$ & $\begin{array}{c}\mathbf{5} \text { years or more } \\
(\mathbf{n = 1 2 8})\end{array}$ \\
\hline Aerophagia \% & 4.23 & 6.25 \\
Swaying \% & 1.88 & 4.69 \\
Stall-walking \% & 6.1 & 3.91 \\
Total & 12.2 & 14.84 \\
\hline
\end{tabular}

No association was found between the presence of individual and total classic stereotypies in connection to the age variable ( $p>0.05)$.

\section{DISCUSSION}

The prevalence of classic stereotypies found in horses at $\mathrm{CHC}$ is well within the range reported in other studies, which varies between 0.7 and $66 \%$ (3-20), and is one of the highest worldwide. In fact, it is the highest reported prevalence among studies done on competing Thoroughbreds $(4,6,8,9,20)$ and those done in South America on Chilean rodeo horses $(16,19)$, sport horses (18), racehorses (20) and military horses (14) which have been reported a frequency of classic stereotypies of 2.32 to $10 \%$. As stereotypies have not been reported in free horses (1), the high prevalence of stereotypies found in $\mathrm{CHC}$ horses could be explained in part by a greater breed predisposition, reported for Thoroughbreds $(4,6,10-13,15)$, associated with the nervous or reactive temperament of this breed (11). The high prevalence may also be hereditary, as it has been shown that there are families with a prevalence 5 to 10 times higher than the
No se encontró asociación entre la presencia de estereotipias clásicas individuales y totales con la variable sexo $(p>0.05)$.

En la tabla 3, se muestra la prevalencia de estereotipias clásicas en caballos FSC del CHC de acuerdo con la edad.

No se encontró asociación entre la presencia de estereotipias clásicas individuales y totales con la variable edad $(p>0.05)$.

\section{DISCUSIÓN}

La prevalencia de estereotipias clásicas encontrada en los caballos del CHC si bien está dentro del rango reportado en otros estudios, el que varía entre $0.7 \%$ y $66 \%(3-20)$, es una de las más alta a nivel mundial. De hecho, es la prevalencia más alta reportada entre los estudios realizados en FSC en competencia $(4,6,8,9,20)$ y los realizados en Sudamérica en caballos de rodeo chileno (16, 19), deporte (18), carreras (20) y uso militar (14) en los que se han reportado frecuencias de estereotipias clásicas de $2.32 \%$ a $10 \%$. Como las estereotipias no han sido reportadas en equinos de vida libre (1), la alta prevalencia de estereotipias encontrada en los caballos del CHC, se podría explicar en parte, por la mayor predisposición racial reportada para los FSC $(4,6,10-13,15)$, asociada al temperamento más nervioso o reactivo de esta raza (11). También a un origen hereditario, ya que se ha demostrado que existen familias con prevalencias 5 a 10 veces mayores al promedio observado en una determinada población de caballos FSC (4).

No obstante, como lo señalan diversos estudios, al parecer más importante que la raza son las condiciones de manejo diario. Dentro de los factores de riesgo a los que son sometidos los caballos del CHC están: estabulación por más de 22 horas diarias $(6,21)$, encierro en pesebreras individuales sin contacto físico con otros caballos $(6,11,19)$, uso de viruta como material de cama $(20,21)$, no tener acceso a un corral o a pastoreo $(8,11)$, alimentación fraccionada (1), basada principalmente en concentrado $(6,11,12)$ y una menor proporción de forraje $(6,12,19,21)$. En relación al sexo, el no haber encontrado asociación significativa con las estereotipias clásicas, coincide con otras investigaciones $(3,11,12,16,22)$.

Tadich et al (19) en un estudio realizado en 325 caballos de raza chilena, encontraron una asociación significativa $(p<0.0001)$ entre el sexo y la presentación de estereotipias, siendo éstas más frecuentes en machos enteros que en machos castrados y hembras. Lo que fue justificado por 
average observed in a determined population of Thoroughbred horses (4).

However, as pointed out by several studies, daily handling conditions are more important than breed. The risk factors to which the $\mathrm{CHC}$ horses are subjected are: stabling for more than 22 hours a day $(6,21)$, confinement in individual stalls without physical contact with other horses $(6,11,19)$, use of shavings as bedding material $(20,21)$, no access to a paddock or to grazing $(8,11)$, prepared feed (1), mainly concentrated $(6,11,12)$ and a lower rate of foraging $(6,12,19,21)$. In relation to sex, no significant association with the classic stereotypies was found, which is consistent with other studies $(3,11,12,16,22)$.

Tadich et al (19) in a study of 325 Chilean horses, found a significant association $(p<0.0001)$ between sex and the appearance of stereotypies, being that they are more common in stallions than in castrated males and females. The finding was justified by these researchers based on the social isolation that stallions are subjected to in Chile, by being kept in paddock and stalls without physical contact and at times without eye contact with other horses. On the other hand, the present study and Tadich et al (19), differ completely with findings reported by Mills et al (9) who conducted a study of 4061 Thoroughbreds, and found that the prevalence of classic stereotypies was higher in geldings $(6.9 \%)$ and mares $(6.4 \%)$ than in stallions (3\%). They suggest that the increased risk in castrated horses may be associated with stress caused by the Gonadectomy which they have undergone.

These contradictory results suggest that sex is not a risk factor in horses without sexual experience and that the reported differences might be more related to specific handling than to the sex itself. Not finding a significant increase in the overall prevalence of stereotypies associated with age is consistent with reported results in other studies $(1,11,16)$. This result was not expected, since it has been reported that the prevalence of stereotypies increases with age $(1,10,11,19,20)$, partly because once stereotypies are acquired, they are very difficult to eliminate (1) and because horses face stressful situations and other risk factors that could stimulate the development of a stereotypy (3) on a daily basis. But on the other hand, due to the fact that some owners believe that stereotypies are imitated (9), and negatively affect health $(1,4)$ and performance $(1,9)$, there is a high probability that a significant percentage of horses with stereotypies have, after a while, been withdrawn from $\mathrm{CHC}$ for poor performance. estos investigadores, por el aislamiento social al que son sometidos los machos enteros en Chile, al ser mantenidos en corrales y pesebreras sin contacto físico y a veces visual con otros equinos. Por otro lado, el presente estudio y el de Tadich et al (19), difieren totalmente con lo reportado por Mills et al (9), quienes en un estudio realizado en 4061 FSC encontraron que la prevalencia de estereotipias clásicas fue mayor en caballos castrados $(6.9 \%)$ y yeguas $(6.4 \%)$ que en machos enteros $(3 \%)$ y sugieren que el mayor riesgo en los caballos castrados podría estar asociado con el estrés provocado por la gonadectomía a la que han sido sometidos.

Estos resultados contradictorios, sugieren que el sexo no es un factor de riesgo en equinos sin experiencia sexual y que las diferencias reportadas podrían estar más asociadas a manejos específicos que al sexo propiamente. El no haber encontrado un aumento significativo de la prevalencia total de estereotipias asociada con la edad concuerda con lo reportado en otros estudios $(1,11,16)$. Este resultado no era el esperado, ya que se ha reportado que la prevalencia de estereotipias aumenta con la edad $(1,10,11,19,20)$, debido en parte a que una vez adquiridas son muy difíciles de eliminar (1) y porque los caballos día a día se enfrentan a situaciones de estrés y otros factores de riesgo que pudieran estimular la presentación de una estereotipia (3). Pero, por otro lado, debido a que algunos propietarios creen que las estereotipias son imitadas (9), y que afectan negativamente la salud $(1,4)$ y rendimiento $(1,9)$, existe una alta probabilidad que un porcentaje considerable de los caballos con estereotipias luego de un tiempo, hayan sido retirados del $\mathrm{CHC}$ por bajo rendimiento.

En este estudio se observó una tendencia al respecto sólo para el caminar en pesebrera. Esto coincide con lo reportado por Mills et al (9), quienes encontraron que el $16.4 \%$ de los caballos FSC de 2 años presentaban alguna estereotipia, porcentaje que disminuía drásticamente hasta los 6 años, no porque éstas habían desaparecido, sino porque la mayor parte de los caballos con estereotipias habían sido vendidos por disminución de rendimiento.

Con relación a la aerofagia con o sin apoyo, la prevalencia encontrada está dentro del rango reportado en otros estudios, la cual varía entre $0.4 \%$ y $14.08 \%(3-6,8-12,14-16,18-20)$. Sin embargo, es la prevalencia más alta entre los estudios realizados en América del Sur, donde el rango reportado no supera el $2.8 \%(14,16,18-$ 20) y la segunda más alta entre los estudios realizados en caballos FSC en competencia en Italia, Suecia, Australia, Reino Unido, EEUU y Chile 
In this study there was a tendency in this respect only for stall-walking. This is consistent with results reported by Mills et al (9), who found that $16.4 \%$ of 2 year old Thoroughbreds had some stereotypies, a percentage that decreased drastically up to 6 years of age, not because the stereotypies were gone, but because most of the horses with stereotypies had been sold due to declining performance.

Regarding cribbing, with or without support, the prevalence found is within the range reported in other studies, which varies between 0.4 and $14.08 \%(3-6,8-12,14-16,18-20)$. However, it is the highest prevalence among studies conducted in South America, where the reported range does not exceed $2.8 \%(14,16$, 18-20) and the second highest among studies conducted on Thoroughbred horses competing in Italy, Sweden, Australia, UK, USA and Chile that reported frequencies between 2.15 and $13.3 \%(4,6,8,9,15,20)$. This high prevalence, and the observed stereotypies in general, could be related to a genetic predisposition $(4,10,15)$ since a prevalence of $30 \%$ cribbing has been reported in some families of Thoroughbreds when the average was $2.4 \%$ (4). The high prevalence could also be associated with handling by the breeder before arriving at the $\mathrm{CHC}$, such as abrupt weaning $(10,26)$, receiving concentrated feed post-weaning $(1,10)$, since according to one study the highest percentage of foals with cribbing display it between 3 and 9 months of age, and at an average age of 5 months (10). In addition, there are risk factors associated with routine handling at $\mathrm{CHC}$ that can stimulate the development of cribbing such as not using straw bedding $(3,20)$, no access to pasture $(3,8,26)$, receiving small amounts of forage $(3,7,21)$, receiving a highly concentrated diet $(3,7,26)$ and not having physical contact with other horses $(3,15,19,26)$.

Normando et al (22) indicate that the type of bedding material does not affect the prevalence of cribbing. Christie et al (3) and Albright et al (15) also suggest that when there is a lack of visual and physical contact the prevalence of cribbing doubles (12.3\%) when compared with horses that have access to pasture (5.9\%), only eye contact $(5.9 \%)$ or limited visual and physical contact $(5.6 \%)$, therefore stress associated with isolation could cause this increase $(15,19)$. Regarding age, and coinciding with the results of this study, other studies also indicate that it is not a risk factor $(3,16,20,21,23)$. However, sex is more contradictory due to the fact that in many studies no association has been found $(3,6,20,21)$, Mills et al (9) found that cribbing was higher in castrated males than in females and stallions. The study que reportan frecuencias entre $2.15 \%$ y $13.3 \%$ $(4,6,8,9,15,20)$. Esta alta prevalencia al igual que lo observado para las estereotipias en general, podría estar relacionada con una predisposición genética $(4,10,15)$ ya que se ha reportado una prevalencia de aerofagia de $30 \%$ en algunas familias de FSC cuando el promedio era $2.4 \%$ (4). También la alta prevalencia, podría estar asociada al manejo recibido en el criadero antes de llegar al CHC como: destete abrupto $(10,26)$, recibir concentrado post destete $(1,10)$, ya que según un estudio el mayor porcentaje de los potrillos que comienzan con aerofagia lo hacen entre los 3 y 9 meses con una edad promedio de 5 meses (10). Además, hay factores de riesgo asociados al manejo rutinario en el $\mathrm{CHC}$ que pueden estimular el desarrollo de aerofagia tales como: no usar cama de paja $(3,20)$, no tener acceso a potrero $(3,8,26)$, recibir poca cantidad de forraje $(3,7,21)$, recibir una dieta alta en concentrado $(3,7,26)$ y no tener contacto físico con otros caballos $(3,15,19,26)$.

Normando et al (22) señalan que el tipo de material de cama no afecta la prevalencia de aerofagia. También Christie et al (3) y Albright et al (15) señalan que cuando falta contacto visual y físico la prevalencia de aerofagia aumenta al doble $(12.3 \%)$ al compararla con caballos que tienen acceso a potrero (5.9\%), sólo contacto visual (5.9\%) o con contacto visual y físico limitado (5.6\%), por lo que el estrés asociado al aislamiento podría provocar este aumento (15, 19). Respecto a la edad, en coincidencia con resultados del presente estudio, asi como otros estudios señalan que no es un factor de riesgo $(3,16,20,21,23)$. Sin embargo, el sexo es más contradictorio ya que si bien, en muchos estudios no se ha encontrado asociación $(3,6,20,21)$, Mills et al (9), encontraron que la aerofagia era mayor en machos castrados que en hembras y machos enteros. Estudio que difiere de otro realizado por Tadich et al (19) en caballos de raza chilena, en donde se encontró que los machos enteros tuvieron mayor frecuencia de aerofagia $(p=0.001)$ que machos castrados y hembras, sugiriendo que esto podría estar más asociado al aislamiento social que al sexo. Además, en ese mismo estudio encontraron que los machos enteros que en un mismo período competían en rodeo chileno y eran utilizados como sementales tenían un mayor riesgo de presentar estereotipias que los que realizaban sólo una función (19).

Con relación al balanceo, también llamado mal del oso (18) o bamboleo (16), la prevalencia encontrada si bien está dentro del amplio rango reportado en otros estudios realizados tanto en América del Sur como en el resto del mundo, la cual varía de $0.1 \%$ a $50 \%(3-6,8,10,13,14,16-$ 
differs from another done by Tadich et al (19) on Chilean horses, where stallions had a higher frequency of cribbing ( $p=0.001$ ) than castrated males and females, suggesting that this could be more related to social isolation than to sex. Furthermore, the same study found that stallions who both competed in the Chilean rodeo and were used as sires in the same period had a higher risk of displaying stereotypies than those engaged in only one function (19).

In regard to weaving, also called swaying (2), the prevalence found is well within the range reported in other studies conducted in both South America and the rest of the world, which varies 0.1 to $50 \%$ $(3-6,8,10,13,14,16-20)$, and is close to the average of other studies of Thoroughbred horses competing in Italy, Sweden, Australia, Chile and the United Kingdom, where reported frequencies are between 0.1 and $5 \%(4,6,8,20)$. Among the risk factors associated with weaving is heritability $(4,11)$. In a study of 1035 Thoroughbreds in Italy where the weaving average was $2.5 \%$, in some families it was $26 \%$ (4). Although not unanimous (10), other studies indicate that breed is a risk factor, the most prevalent breeds being Thoroughbred $(11,13)$ and Arab (17), perhaps associated with their more reactive temperament (13) or with the athletic activity that they perform (6). It has also been observed in Thoroughbred competing that the prevalence is higher in horses stabled all day than those who had access to pasture for a few hours $(8,21)$.

Christie et al (3) found no association with access time to a pasture. They have also identified other risk factors such as not having access to a paddock (22), receiving less than $6.4 \mathrm{~kg}$ of forage per day (21) and being a brood mare mother without young (17). Furthermore, Ninomiya et al (13) suggest that it could be imitated by means of social learning; however, Clegg et al (27), discard that. With regard to gender, the results are contradictory because, like the present study, others indicate no other association with weaving $(3,10,16,19,28)$. However, the study by Mills et al (9) conducted in 4061 horses indicated that the frequency of weaving was higher in females $(2.13 \%)$ than in stallions $(0.57 \%)$ and geldings $(0.63 \%)$. Also, the study conducted by Tadich et al (20) on 743 competing Thoroughbreds reported that the frequency was higher in females $(3.04 \%)$ and stallions $(2.52 \%)$ than in geldings $(0.48 \%)$. With regard to gender, there was a striking result from the study conducted by Behjahali et al (17) on breeding Arabian mares, which reported that $21.9 \%$ of broodmares displayed weaving, suggesting a relationship with sex. However, in that same study, of the 25 females with weaving, just 1 was foaling and the rest had no nursing young with them. The
20), es cercana al promedio de otros estudios realizados en caballos FSC en competencia en Italia, Suecia, Australia, Chile y Reino Unido, los que reportan frecuencias entre 0.1 y $5 \%$ $(4,6,8,20)$. Dentro de los factores de riesgo asociados al balanceo está la heredabilidad (4, 11) ya que en un estudio realizado a 1035 FSC en Italia en donde el promedio de balanceo era de $2.5 \%$, en algunas familias éste era de $26 \%$ (4). Aun cuando, no hay unanimidad (10), otros estudios señalan que la raza es un factor de riesgo, siendo las razas con mayor prevalencia los FSC $(11,13)$ y árabe $(17)$, tal vez asociado con su temperamento más reactivo (13) o a la actividad deportiva que realizan (6). También, ha sido observado en FSC en competencia, que la prevalencia es mayor en caballos estabulados todo el día que los que tenían acceso a potrero algunas horas $(8,21)$.

Christie et al (3), no encontraron asociación con el tiempo de acceso a un potrero. Además, han sido identificados otros factores de riesgo como: no tener acceso a un corral (22), recibir menos de $6.4 \mathrm{~kg}$ de forraje al día (21) y ser yegua madre sin cría al pie (17). Por otro lado, Ninomiya et al (13), sugieren que podría ser imitado por aprendizaje social; sin embargo, Clegg et al (27), lo descartan. Con relación al sexo, los resultados son contradictorios ya que al igual que en el presente estudio, otros señalan que no tendría asociación con la presentación de balanceo $(3,10,16,19,28)$. Sin embargo, el estudio de Mills et al (9), realizado en 4061 caballos señaló que la frecuencia de balanceo fue mayor en hembras $(2.13 \%)$ que en machos enteros $(0.57 \%)$ y machos castrados $(0.63 \%)$. También, el estudio realizado por Tadich et al (20), en 743 caballos FSC en competencia reportó que la frecuencia fue mayor en hembras (3.04\%) y machos enteros $(2.52 \%)$ que en machos castrados $(0.48 \%)$. Con relación al sexo, llama la atención el resultado del estudio realizado por Behjahali et al (17) en un criadero de yeguas árabes, que reportó que el $21.9 \%$ de las yeguas madres presentaba balanceo, lo que sugiere alguna relación con el sexo. Sin embargo, en ese mismo estudio, de las 25 hembras con balanceo, sólo 1 estaba en período de lactancia y el resto no tenía cría al pie. La diferencia reportada entre las yeguas madres con cría y sin cría al pie, en ese estudio se podría explicar por un lado por el estado hormonal asociado a la lactancia o más probablemente por un aspecto social asociado al tener o perder el lazo madre-cría.

Respecto a la edad, el estudio realizado por Waters et al (10), mostró que la edad promedio de inicio de balanceo era la semana 60 . En otro estudio Christie et al (3), encontraron que la frecuencia 
reported difference between mares with or without a nursing foal in that study could be explained by the hormonal state associated with lactation or most likely by a social aspect associated with having or losing the mother-foal bond.

Regarding age, the study conducted by Waters et al (10) showed that the average age of onset for weaving was week 60. In another study Christie et al (3) found that the frequency was higher in individuals older than 10 years of age, which they justified by noting that increasing age increases the likelihood of encountering stressful situations. However, other studies conducted on competing horses showed no differences associated with age $(12,16,19)$.

With regard to stall-walking, also called box-walking (2), the prevalence found was well within the range reported in other studies in both South America and the rest of the world, which varies between 0.2 and $8.8 \%(4-8,10,13,16-20)$, and is the fourth highest worldwide. But, the highest among the studies performed on Thoroughbred horses competing in Italy, Sweden, Australia, Chile and the United Kingdom reported frequencies from 0.2 to $3.9 \%$ $(4,6,8,20,21)$. Although it is believed that the cause is associated with social needs (1), two studies have shown that there is a genetic predisposition $(4,10)$ and that there has been a prevalence of stall-walking of $13 \%$ in some Thoroughbred families in circumstances where the average for the same study was $2.5 \%$ (4). However, other studies indicate that risk factors are also: lack of physical contact with other horses (11), no access to pasture $(8,11,28)$ and breed, as it is reported to be more common in Thoroughbred $(6,11)$ Arab (17) and Warm-blood horses, perhaps for being more reactive breeds (11). It is speculated that the cause may be motivation to keep moving, frustration or little environmental stimulation (1). With regard to sex, some studies indicate that this would not be a risk factor $(9-11,19,22)$. Although Muñoz et al (16), in a study performed on 100 Chilean horses, found that it was significantly more frequent $(p<0.05)$ in stallions $(6 \%)$ than in females $(0 \%)$, suggesting that it could be associated with the handling to which they are subjected in Chile because they remain stabled all day, without physical contact and sometimes without eye contact with other horses.

On the contrary Tadich et al (20) observed that stall-walking in Thoroughbreds was more common in mares $(3.72 \%)$ than in geldings $(1.44 \%)$ and stallions $(0.42 \%)$. Regarding age, the average age of onset for stall-walking is 64 weeks (10) and this should increase with age (1). However, in accord with the present study, no association between the prevalence of stall-walking and age $(11,16,19,28)$ was found. Although, in this study, a decreasing fue mayor en individuos mayores a 10 años, lo que justificaron, señalando que al aumentar la edad aumenta la posibilidad de encontrarse con situaciones estresantes. Sin embargo, otros estudios realizados en caballos en competencia no muestraron diferencias asociadas a la edad $(12,16,19)$.

Con relación al caminar en pesebrera, también llamado paseo circular en pesebrera (16) o caminar estereotipado (18), la prevalencia encontrada si bien estuvo dentro del rango reportado en otros estudios realizados tanto en América del Sur como en el resto del mundo, la cual varía entre $0.2 \%$ y $8.8 \%(4-8,10,13,16-20)$, es la cuarta más alta a nivel mundial. Pero, la más alta entre los estudios realizados en caballos FSC en competencia en Italia, Suecia, Australia, Chile y Reino Unido que reportan frecuencias de $0.2 \%$ a $3.9 \%(4,6,8,20,21)$. Aún cuando, se cree que su causa está asociada a necesidades sociales (1), dos estudios han mostrado que existe una predisposición genética $(4,10)$ ya que se ha observado una prevalencia de caminar en pesebrera de $13 \%$ en algunas familias de FSC, en circunstancias que el promedio en ese mismo estudio era de $2.5 \%$ (4). No obstante, otros estudios señalan que también son factores de riesgo: la falta de contacto físico con otros caballos (11), no tener acceso a potrero $(8,11,28)$ y la raza ya que se reporta que es más frecuente en caballos FSC $(6,11)$, árabes (17) y de sangre templada, tal vez por ser razas más reactivas (11), por lo que se especula que las causas podrían ser una mayor motivación a seguir moviéndose, frustración o poca estimulación ambiental (1). Con relación al sexo, algunos estudios señalan que éste no sería un factor de riesgo $(9-11,19,22)$. Aun cuando Muñoz et al (16), en un estudio realizado en 100 caballos de raza chilena, encontraron que fue significativamente más frecuente $(p<0.05)$ en machos enteros (6\%), que en hembras (0\%), sugiriendo que podría estar asociado al manejo al que son sometidos los machos enteros en Chile, ya que permanecen estabulados casi todo el día, sin contacto físico y a veces tampoco visual con otros caballos.

Contrariamente Tadich et al (20), observaron que el caminar en pesebrera en caballos FSC fue más frecuente en yeguas (3.72\%), que en machos castrados $(1.44 \%)$ y machos enteros $(0.42 \%)$. Con relación a la edad, el promedio de inicio de caminar en pesebrera en caballos es 64 semanas (10) y ésta debería aumentar con la edad (1). Sin embargo, en coincidencia con el presente estudio no se encontró asociación entre la prevalencia de caminar en pesebrera y la edad $(11,16,19,28)$, aún cuando, en este estudio se observó una tendencia de disminución de esta estereotipia 
trend was observed for this stereotypy in horses 5 years of age or more, which suggests that horses that display stall-walking are discarded due to poor performance.

It is suggested that the prevalence of stereotypies in general and stall-walking in horses at $\mathrm{CHC}$, the highest reported in competing Thoroughbred horses, is a consequence of the stressful handling they undergo at the $\mathrm{CHC}$, which does not allow the expression of normal social, nutritional, sexual and kinetic behavior. On the other hand, not finding an association between the presence of stereotypies and sex could result from a similar handling of individual horses without general sexual experience, or maternal experience in the case of females. Finally, not finding a significant increase in stereotypies associated with age could explain why a significant percentage of horses with stereotypies are discarded from competition for low performance, which apparently occurs mainly in horses that display stall-walking.

In conclusion, Thoroughbred horses at the $\mathrm{CHC}$ have a high prevalence of classic stereotypies, mainly stall-walking. en caballos de 5 años o más, lo que hace pensar que los caballos con caminar en pesebrera son descartados por mal rendimiento.

Se sugiere que el hecho de que la prevalencia de estereotipias en general y de caminar en pesebrera en los caballos del $\mathrm{CHC}$, sea la más alta reportada en caballos FSC en competencia, es consecuencia del manejo estresante al que son sometidos los caballos en el CHC, lo que no permite la expresión normal de su comportamiento social, alimenticio, sexual y cinético. Por otro lado, el no encontrar asociación entre la presencia de estereotipias y el sexo puede ser consecuencia de un manejo similar en individuos sin experiencia sexual en general y experiencia materna en el caso de las hembras. Finalmente, el no haber encontrado un aumento significativo de estereotipias asociado a la edad se podría explicar porque un porcentaje importante de los caballos con estereotipias son descartados de la competencia por bajo rendimiento, lo que en forma aparente ocurre principalmente en caballos que presentan caminar en pesebrera.

En conclusión los caballos FSC del CHC presentan una alta prevalencia de estereotipias clásicas, principalmente caminar en pesebrera.

\section{REFERENCES}

1. McGreevy P. Equine behavior. A guide for veterinarians and equine scientists. Philadelphia: Saunders; 2004.

2. McDonnell S. A practical field guide to horse behavior: the equid ethogram. Hong Kong: The Blood-Horse Inc; 2003.

3. Christie JL, Hewson CJ, Riley CB, McNiven MA, Dohoo IR, Bate LA. Management factors affecting stereotypies and body condition score in nonracing horses in Prince Edwards Island. Can Vet J 2006; 47:136-143.

4. Vecchiotti GG, Galanti R. Evidence of heredability of cribbing, weaving and stall walking in thoroughbred horses. Livest Prod Sci 1986; 14:91-95.

5. Dodman NH, Normile JA, Cottam N, Guzman M, Shuster L. Prevalence of compulsive behaviors in formerly feral horses. Intern J Appl Res Vet Med 2005; 3:20-24.
6. Rebdo I, Rebdo-Torstensson P, Ödberg FO, Hedendahl A, Holm J. Factors affecting behavioural disturbances in race-horses. Anim Sci 1998; 66:475-481.

7. Parker M, Goodwin D, Redhead ES. Survey of breeders' management of horses in Europe, North America and Australia: comparison of factors associated with the development of abnormal behaviour. Appl Anim Behav Sci 2005; 114:206-215.

8. Pell SM, McGreevy PD. Prevalence of stereotypic and other problem behaviours in thoroughbred horses. Aust Vet J 1999; 77:678-679.

9. Mills DS, Alston RD, Rogers V, Longford NT. Factors associated with the prevalence of stereotypic behaviour amongst thoroughbred horses passing through auctioneers sales. Appl Anim Behav Sci 2002; 78:115-124. 
10. Waters AJ, Nicol CJ, French NP. Factors influencing the development of stereotypic and redirected behaviours in young horses: findings of a four year prospective epidemiological study. Equine Vet J 2002; 34: 572-579.

11. Bachmann I, Audigé L, Stauffacher M. Risk factors associated with behavioural disorders of crib-biting, weaving and box-walking in Swiss horses. Equine Vet J 2003; 35:158-163.

12. Ahmadinejad M, Habibi P. Il comportamento anormale dei cavalla nei circoli di equitazione di Tehran. Ippologia 2005; 16:33-35.

13. Ninomiya S, Sato S, Sugawara K. Weaving in stabled horses and its relationship to other behavioural traits. Appl Anim Behav Sci 2007; 106:134-143.

14. Pagliosa GM, Alves GES, Faleiros RR, Leal $B B$, Ening MP. Estudo epidemiológico de estereotipias em eqüinos de cavalaria militar. Arch Vet Sci 2008; 13:104-109.

15. Albright JD, Mohammed HO, Heleski CR, Wickens CL, Houpt KA. Crib-biting in US horses: breed predispositions and owner perceptions of aetiology. Equine Vet J 2009; 41:455-458.

16. Muñoz L, Torres J, Sepúlveda O, Rehhof C, Ortiz R. Frecuencia de comportamientos anormales estereotipados en caballos criollo chileno estabulados. Arch Med Vet 2009; 41:73-76.

17. Benhajali $H$, Richard-Yris $M-A$, Ezzaouia $M$, Charfi F, Hausberger M. Reproductive status and stereotypies in breeding mares: a brief report. Appl Anim Behav Sci 2010; 128:64-68.

18. Márquez C, Escobar A, Tadich TA. Características de manejo y conducta en caballos estabulados en el sur de Chile: estudio preliminar. Arch Med Vet 2010; 42:203-207.

19. Tadich T, Smulders JP, Araya O, Nicol CJ. Husbandry practices associated with the presentation of abnormal behaviours in chilean creole horses. Arch Med Vet 2012; 44:279-284.
20. Tadich T, Weber C, Nicol CJ. Prevalence and factors associated with abnormal behaviors in chilean racehorses: a direct observational study. J Equine Vet Sci 2013; 33:95-100.

21. McGreevy PD, Cripps PJ, French NP, Green LE, Nicol CJ. Management factors associated with stereotypic and redirected behaviour in the thoroughbred horse. Equine Vet J 1995; 27:86-91.

22. Normando S, Meers L, Samuels WE, Faustini M, Ödberg FO. Variables affecting the prevalence of behavioural problems in horses. Can riding style and other management factors be significant?. Appl Anim Behav Sci 2011; 133:186-198.

23. Whisher $L$, Raum M, Pina L, Perez L, Erb $H$, Houpt C, Houpt K. Effects of environmental factors on cribbing activity by horses. Appl Anim Behav Sci 2011; 135:63-69.

24. Instituto Geográfico Militar de Chile. Atlas geográfico para la educación. 6 ed. Santiago (Chile): Instituto Geográfico Militar de Chile; 2002.

25. Martin P, Bateson P. Measuring behaviour an introduction guide. $3^{\text {ed }}$. Cambridge: Cambridge University Press; 2007.

26. Wickens $C L$, Heleski CR. Crib-biting in horses: a review. Appl Anim Behav Sci 2010; 128:1-9.

27. Clegg HA, Buckley P, Friend MA, McGreevy PD. The ethological and physiological characteristics of cribbing and weaving horses. Appl Anim Behav Sci 2008; 109:68-76.

28. Bachmann I, Bernasconi P, Herrmann R, Weishaupt MA, Stauffacher M. 2003. Behavioural and physiological responses to an acute stressor in crib-biting and control horses. Appl Anim Behav Sci 2003; 82:297-311. 